\title{
METHOD OF MATHEMATICAL MODELING IN THE MELIORATIVE GEOGRAPHY AND RECREATION
}

\begin{abstract}
В. О. РезУненко, Ю. Ф. Кобченко, О. Ю. Кобченко. МЕТОД МАТЕМАТИЧНОГО МОДЕЛЮВАННЯ В МЕЛІОРАТИВНІЙ ГЕОГРАФІЇ ТА РЕКРЕАЦІї. У меліоративній географії об' єктом дослідження є природно-агромеліоративні системи, які вивчаються різними методами, в тому числі, і методом математичного моделювання. Для їх дослідження нами запропонована математико-фізико-статистична модель зв'язку врожайності сільськогосподарських культур з природними факторами. Проаналізувавши статистичні показники гідрометеорологічних умов у Харківській області, нами встановлено, що кількісна залежність врожаю від числа посушливих днів має складну нелінійну багатопараметричну форму. При иьому тіснота зв'язку врожайності кукурудзи і иукрових буряків з погодними умовами виявилась дуже значною, на що вказує великий коефіиієнт кореляиії між ними, який дорівнює 0.87-0.90. Нами відпрацьована гіпотеза про вид функиіональної залежності між иими ознаками. Використання методу математичного моделювання для аналізу просторовочасової структури розвитку природно-антропогенних явищ дозволяє уніфікувати гідрометеорологічні характеристики $і$ це може бути використано у різних галузях науки, $i$ зокрема в рекреачійній географії. Відзначено, що рекреаційна географія $\epsilon$ новітньою галуззю знання, де чільне місие у наукових дослідженнях займають математичні методи. У роботі запропонована модель природно-рекреаційної системи, що дозволяє впроваджувати комплексне вивчення міждисциплінарних зв 'язків досліджуваних об'єктів. Особливість моделі полягає в тому, щьо вона дозволяє охопити всі етапи розвитку систем, починаючи з планування, проектування і створення рекреаційних систем, i закінчуючи очінкою і прогнозом їх функиіонування.

Ключові слова: меліоративна географія, природно-агромеліоративна система, рекреачія, сільське господарство, погода, клімат, гідрометеорологічні характеристики, математичні методи, моделювання.

В. А. РезУненко, Ю. Ф. Кобченко, О. Ю. Кобченко. МЕТОД МАТЕМАТИЧЕСКОГО МОДЕЛИРОВАННЯ В МЕЛИОРАТИВНОЙ ГЕОГРАФИИ И РЕКРЕАЦИИ. В мелиоративной географии объектом исследования являются природноагромелиоративные системы, которые изучаются разными методами, в том числе и методом математического моделирования. Для их исследования нами предложена математико-физико-статистическая модель связи урожайности сельскохозяйственных культур с природными факторами. Проанализировав статистические показатели гидрометеорологических условий в Харьковской области, нами установлено, что количественная зависимость урожая от числа засушливых дней имеет сложную нелинейную многопараметрическую форму. При этом теснота связи урожайности кукурузы и сахарной свекль с погодныли условиями выявилась значительной, на что указывает большой коэффициент корреляции между ними, который достигает значений 0.87-0.90. Нами отработана гипотеза о виде функциональной завимости между этими признаками. Использование метода математического моделирования для анализа пространственно-временной структуры развития природно-антропогенных явлений позволяет унифицировать гидрометеорологические характеристики и это может быть использовано в различных областях науки, и в частности в рекреационной географии. Отмечено, что рекреационная география является новейшей областью знаний, в научных исседованиях которой важное место занимают математические методы. В работе предложена модель природно-рекреаиионной системь, которая использует комплексное изучение междисииплинарных связей исследуемых объектов. Особенность метода состоит в том, что он даёт возможность охватить все этапы развития системы, начиная с планирования, проектирования и создания рекреационной системы, и заканчивая оценкой и прогнозом её функционирования.
\end{abstract}

Ключевые слова: мелиоративная география, природно-агромелиоративная система, рекреация, сельское хозяйство, погода, климат, гидрометеорологические характеристики, математические методы, моделирование.

Formulation of the problem. Naturalagromeliorative system, as an object of research in the field of meliorative geography, is studied by various methods, among which the main place is occupied by mathematical methods and, in particular, modeling. The study of natural phenomena and anthropogenic activity without the use of mathematical methods is considered onesided, since this does not take into account one of the important aspects of any study -quantitative relationships and regularities. On the other hand, the expediency of their application is due to the fact that recreational geography as a branch of research is relatively new[19]. Theoretical comprehension of recreational processes and methods of research has become the subject of special study, and many problems of recreation cannot be solved within the limits of geography, sociology, medicine or wellbeing, since recreational activity has become an interdisciplinary subject [3].

Analysis of recent research and publications. For the first time, mathematical methods in geography were proposed in the 20-th of the twentieth century by geographers V.P. Semenov-Tian-Shansky and M. M. Protodiakonov. Academicians A. A. Grigoriev and D. L. Armand developed the idea of mathematical engineering in geography. The first work on mathematical statistics in geography was published by V.A. Chervyakov (1966). In 1968 the success of mathematical methods application in geography allowed to hold the first All-Union meeting on the given problem on the basis of Moscow University. This gave impetus to their further widespread use in all branches of geographic science [2]. Moscow scientists (K.N. Dyakonov, L.V. Kantorovich, V.S. Mikeheev, Yu.G. Pusachenko, V.S. Tikunov), S. Petersburg (P.P. Arapov, V.S. Zekulin, 
Yu.P. Seliverstov), Kazan (Yu.R. Arhipov, O.M. Trofimov), Kyiv (M.D. Hrodzinsky, V.S. Davychuk, P.O. Maslyak), Lviv (O.T. Vaschenko, V.S. Gritsevich, A.I. Shabliy), Minsk (G.N. Shakok, M.K. Chertkov), Odessa (O.G. Topchiev, V.G. Svitlichny, G.I. Shevbes), Simferopol (M.V. Bagrov, V.O.Bokov, K.G. Vobly), Kharkiv (I.G.Chervanev, A.P.Golikov, V.Yu.Nekos) fully used various sections of mathematics, including methods of mathematical modeling, in their theoretical and experimental studies. They have found wide application in reclamation geography. Thus, V.S. Anoshko [1], M.I. Budyko, S.A. Vladicinsky, V.G. Voropayev, R. A. Kasmanov, P. I. Koloskov, A. M. Shulgin made a significant contribution to its development. In many fields of recreational geography, these methods were developed by O.O. Beydyk, P.O.Maslyak, V.S.Pankov, T.P.Panchenko, I.E.Timchenko, V.I.Stafiychuk, N.V. Khomenko, I.M. Yakovenko and others.

We have certain experience in this field $[8,9$, 10]: a concept of "natural agromeliorative system" has been substantiated and its model is proposed; method of natural-agromeliorative estimation of landscapes has been developed; the role of natural processes and anthropogenic factors in the development of natural and human-made systems has been assessed. Application of mathematical methods is given considerable attention to in scientific research and in the educational process when studying the courses "Meteorology and Climatology", "Climate of Ukraine", "Recreational Geography". In the article on the basis of this experience an attempt was made to analyze the spatial-temporal structure of natural and man-made phenomena development on the territory of Kharkiv region and to apply these developments for a more objective and effective compilation of the generalized information.

Purpose of the article. The main purpose of the work is to analyze the structure of naturalagromeliorative and recreational systems by method of mathematical modeling. In studying these issues it is necessary to objectively assess distribution of these phenomena, therefore the following tasks are determined in the work: to study initial preconditions for the research; analyze statistical data; to determine empirical connections of the spatialtemporal structure of these systems by the method of mathematical modeling.

Presentation of the main research material. In meliorative geography, the object of research is the natural agromeliorative systems, studied by various methods, including by the method of mathematical modeling [7]. We have proposed a mathematical-physical-statistical model of the connection of crop yields with natural factors. This allowed us to assess the agrometeorological, soil and landscape-climatic resources of growing crops and determine their contribution to the process of harvesting. To determine the dependence of biomass and harvest growth on weather conditions, they were used as their own meteorological data for expeditionary researches of the hydrometeorological laboratory at the V.N. Karazin KhNU, as well as the data of the networked meteorological stations of Kharkiv region for the period of 1972-2016. The analysis has showed that in different parts of the region there are significantly different crop yields. Variation of crop yields depends on many natural factors, the leading place among which belongs to soil and climatic factors. To determine the functional relationship (tightness of communication) of crop yields with soil conditions, we considered the stock of humus in soils. Specifically, we have considered corn and sugar beet which are very important for Kharkiv region. At the same time, we took into account deviation of these crops yield from the average in the region. The correlation coefficient between deviation of yield and soil conditions for these crops is low $(0.15-0.26)$, which indicates that this factor is not the leading factor in variability of yield in the region. At the same time, close connection between the yield of corn and sugar beets with weather conditions turned out to be very high, as indicated by the large correlation coefficient between them, which equals $0.87-0.90$. This is especially true in arid years.

According to long-term expeditionary observations, it was discovered that the quantitative dependence of the crop on the number of dry days had a complex non-linear multi-parameter representation. We worked out a hypothesis about the form of functional dependence between these features [8]. They were plotted on a plane in the Cartesian coordinate system, and using a significant number of different standard schedules obtained, it was established that the functional dependence of crop yields deviation on the average in the region and the number of dry days is related to the hyperbolic type. This type was determined to be:

$$
\mathrm{Y}=\mathrm{a} /(\mathrm{x}-\mathrm{b})+\mathrm{c}
$$

Applying the least square method, nonlinear systems of equations are solved and the following specific functional dependences are obtained for

$$
\begin{aligned}
& \text { Corn } Y=\frac{32.7}{H-3.3}-12.2, \\
& \text { Sugar beets } Y=\frac{12.6}{H-3.9}-7.1,
\end{aligned}
$$

where: $Y-$ crop deviation from the average in the region, $H$ - number of days with arid weather conditions. 


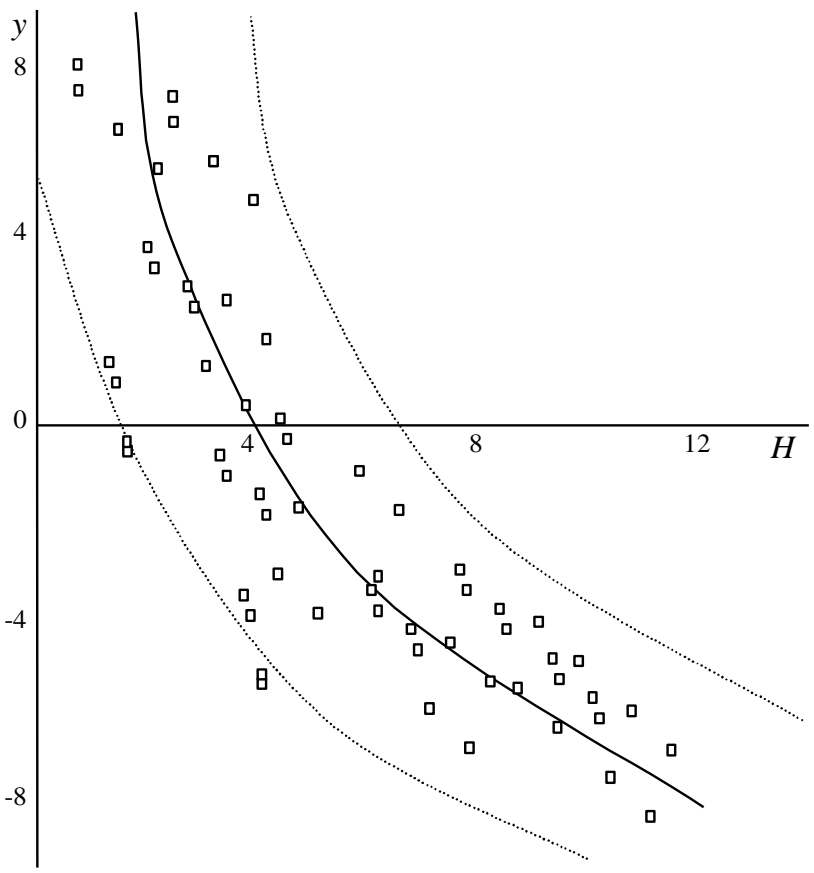

Fig. 2. Dependence of the deviation of corn crop $(Y)$ on the number of days with arid phenomena $(H)$

As shown by the graph (Fig. 2) and calculations of the dependence of crop yields deviation on the number of days with arid phenomena, the most significant progressing crop losses are observed in the first 4-6 days of the arid phenomena development. This loss process is gradually stabilized and is approaching a certain point, sometimes critical, probably due to the critical adaptability of plants to adverse conditions. Thus, for example, in irrigation, it is very important not to miss a single day with arid phenomena, because it has the most devastating effect on the plants. As expected from the results of the calculations, it is necessary to take into account the fact that there is a close connection between crop yields and hydrometeorological factors. This is to a certain extent confirmed by the results of the correlation dependency calculations given in the table, graphic materials, as well as by calculations of the probability criterion, determined by the rule of three sigmas. It also confirms relation of natural and economic features. The discovery of quantitative relations of crops to the weather factors allows us to calculate crop yields in each particular case. This technique can form the basis for crop yields forecast.

On the other hand, the feasibility of mathematical methods is due to the fact that such a branch of research as recreational geography has appeared relatively recently.Theoretical comprehension of recreational processes and introduction of mathematical methods became the subject of special study only in the second half of 20th century [18]. This was largely due to the fact that many recreational problems could not be resolved within the limits of geography, sociology, medicine or val- eology; thus recreational activity became an interdisciplinary object $[16,17]$.

In this paper a model of the natural-recreational system (NRS) is proposed, the elements of which are diverse yet interrelated objects. The model gives an opportunity to highlight various aspects of NRS research. Thus, the socio-economic aspect of the NRS, studied by social sciences, gives an opportunity to highlight organizational, economic, socio-economic problems; technical sciences within the framework of NRS are related to the study, design, construction and operation of recreational systems; agricultural sciences - to study ways of introducing means of intensifying the economy [18]; the recreational aspect considers the natural environment as a natural prerequisite, the sphere of recreation.

The model allows to distinguish two levels of research: monodisciplinary and interdisciplinary. The monodisciplinary method of research is characterized by the unity of the subject and method of research, and is carried out within the limits of separate sciences. The interdisciplinary level refers to the specific type of problem research of the NRS, the purpose of which is to comprehensively study the interdisciplinary connections of the objects being studied. Its peculiarity lies in the fact that it allows to cover all stages of the NRS development, from planning, design and creation of recreational systems, and ending with the assessment and forecast of their functioning.

At the planning and design stages of the NRS, the need for recreation and the possibility to conduct them in separate areas according to the peculiarities of their natural conditions is determined. When 
determining the strategy and tactics of a recreational complex formation, the first principal stage of recreation in the region is the question of the official definition of the place and role of this industry in the economic structure of the region, and accordingly, the definition of practical actions course at different levels of government.

Considerations of the economic expediency of recreational potential use suggest that this industry should become an equal area of interests and assistance to public authorities. They define a general strategy of action and a mode of economic assistance, implement geographically sound economic regulations for the development of recreational spheres.

At the NRS operation stages the level of its functioning is studied. This is determined by a set of ecological and economic methods based on modeling the empirical relationships of the state and the development of recreational systems, depending on the leading natural-anthropogenic factors. By attracting natural objects, cultural-historical and ethnoethnographic complexes, technical systems and other components of recreational potential into the sphere of recreation, the researcher finds and formulates, and the society develops, special territorial recreational systems.
The predicted level of NRS functioning should be provided with a set of evaluation and economic methods based on modeling the empirical relationships of the state and recreation development caused by leading natural and anthropogenic factors.

Conclusions. Thus, after considering the study of natural agro-ameliorative and recreational systems, we can draw the following conclusions. A characteristic feature of modern scientific research is the integral process, which contributes to the emergence of new scientific directions. In the field of reclamation and recreational geography, the mathematical methods occupy a pivotal place in scientific research. The proposed mathematicalphysical-statistical model of the naturalagromeliorative system allows us to implement a comprehensive study of interdisciplinary links of investigated objects. Its peculiarity lies in the fact that it provides an opportunity to cover all stages of systems development: from planning, designing and creating recreational systems, and ending with the estimation and forecast of their functioning. Mathematical methods of analysis of natural and man-made phenomena spatial-temporal structure development allow us to unify the leading traits of the system, which can be used to solve practical problems in various branches of the economy.

1. Аношко, В. С. Мелиоративная география Белоруссии [Текст] / В. А. Аношко. - Минск :БГУ, 1989. - 387 с.

2. Арманд, Д. Л. Опьт математического анализа связи между растительностью и климатом [Текст] // Изв. ВГО. - T. 82, Bbin. 1. -1976. - C. 54-61.

3. Бейдик, О. О. Словник-довідник з географії туризму, рекреалогії та рекреаційної географії [Текст] / O. О. Бейдик. - К. : Палітра, 1997. - 130 c.

4. Голояд, Б. Я. Рекреаційно-туристський напрям господарювання - застава добробуту краян Прикарпаття. [Текст] / Б. Я. Голояд, І. В. Римарчук. - Івано-Франківськ : Рух, 2013. - 32c.

5. Заставний, Ф. Д. Географія України. [Текст] - Львів : Світ, 1994. - 472 с.

6. Клімат Украӥни [Текст] / За ред. В. М. Ліпінського, В. А. Дячука, В. М. Бабіченко. - Київ : Вид-во Раєвського, 2003. -343 c.

7. Кобченко, Ю. Ф. Фітопогодний комплекс як система [Текст] / Ю.Ф.Кобченко // Вісн. Харк. ун-ту. Серия «Геология-География-Экология». - 2006. - № 753. - С. 80-85.

8. Кобченко, Ю. Ф. Еколого-меліоративни моніторинг як метод дослідження складних систем [Текст] / Ю. Ф. Кобченко, В. М. Клименко, О. І. Протасов // Вестн ХИСП. - 2002. - № 75.- С. 121-126.

9. Кобченко, Ю. Ф. Применение статистического критерия ХИ-квадрат для анализа гидрометеорологической информации и прогнозирования развития погодных комплексов [Текст] / Ю. Ф. Кобченко, В. А. Резуненко, Н. А. Гвоздь // Вестн. Харьк. ун-та. Серия «Геология-География-Экология». - 2003. - № 61. - C.143-150.

10. Кобченко, Ю.Ф. Обработка гидрометеорологической экспериментальной информации методом системы кривых Пирсона [Текст] / Ю. Ф. Кобченко, В. О. Резуненко // Материаль конференции «Каразинские природоведческие студии». - Харьков : ХНУ. - 2004. - С.287-290.

11. Кравців, В. С. Рекреаційна політика в Карпатському регіоні: принципи формування, шляхи реалізації [Текст] / В. С. Кравиів, В. К. Свдокименко, М. М. Габрель. - Чернівиі : "Прут", 2013. - 72 с.

12. Масляк, П. О. Рекреаційна географія [Текст] / П. О. Масляк. - К. : Лібра, 2010. - 397 с.

13. Павлов, В. І., Черчик Л. М. Рекреаційний комплекс Волині: теорія, практика, перспективи [Текст] / В. I. Павлов, Л. М. Черчик. - Луизьк: "Надстир'я", 2012. - 122 с.

14. Паламарчук, М. М. Природно-ресурсний потенціал сталого розвитку Украӥни [Текст] / М. М. Паламарчук, Б. М. Данилишин, С. І. Дорогунщов. - Київ : РВПС Украӥни, 1999. - 716 с.

15. Пузаченко, Ю. Г. Математические методі в екологических и географических исследованиях [Текст] / Ю. Г. Пузаченко. - М. : Академия, 2004. - 416 с.

16. Стафійчук, В. І. Рекреалогія [Текст] : навчальний посібник / В. I. Стафійчук. - 2-е вид. - К. : Альтерпрес, 2008. $-264 c$ 
17. Фоменко, Н. В. Рекреаційні ресурси та курортологія. Навчальний посібник [Текст] / Н. В. Фоменко. - К. : Центр навчальної літератури, 2007. - 312 c.

18. Цьохла, С. Ю. Трансформація рекреаційної діяльності та розвиток регіональних ринків курортнорекреаційних послуг (методологія, аналіз і шляхи вдосконалення): монографія [Текст] / С. Ю. Цьохла. Сімферополь : Таврія, 2012. - 352 с.

19. Черванев, И. Г. Математические методы в географии [Текст] / И. Г. Черванев, А. П. Голиков, А. М. Трофимов. - Харьков. : ХГУ,1986. - 348 с.

20. Шищенко, П. Прикладна фізична географія [Текст] / П. Г. Шищенко. - К. : Либідь, 2003. - 343 с.

UDC 338.483(477.54)

*S. I. Reshetchenko, PhD (Geography), Associate Professor,

*N. I. Cherkashyna, Senior Lecturer,

**O. V. Babaieva, PhD (Geography), Associate Professor,

*V. N. Karazin Kharkiv National University,

** Institute of Trade and Economics

\section{PHYSICAL AND GEOGRAPHICAL PRINCIPLES OF TOURIST CLUSTER'S FORMATION IN KHARKIV REGION}

С. І. Решетченко, Н. І. Черкашина, О. В. Бабаєва. ФІЗИКО-ГЕОГРАФІЧНІ ЗАСАДИ ФОРМУВАННЯ ТУРИСТИЧНОГО КЛАСТЕРУ ХАРКІВСЬКОЇ ОБЛАСТІ. У статті розглядаються основні фізико-географічні фактори (кліматичні, водні, лісові, рельєф) формування туристичного кластеру на території Харківської області. Кластерний підхід дає змогу визначити пріоритетні напрямки розвитку туристичної діяльності, максимально використовувати природні умови та проводити природоохоронні заходи. Сьогодні туристичний кластер виступає як інновачійна форма розвитку регіональної економіки, отже туризм є одним із факторів соціально-економічного функиіонування території. Туристично-рекреаційна діяльність також відіграє головну роль у міжнародно-економічних зв 'язках. Формування туристичного кластеру території дозволить ефективно використовувати всі доступні туристично-рекреаційні ресурси регіону. Дослідження кліматичних показників проводилося за допомогою статистичного методу, де аналізувалися часові ряди середньомісячних значень температури повітря, атмосферних опадів, сонячної радіації за період 2001-2015 рр. За методикою Н.В. Фоменко встановлено, що територія Харківської області для рекреаиії та туристичної діяльності за показниками «клімат», «лісові ресурси», «рельєф» характеризується оцінкою «добре». В той же час за показником «водні ресурси» досліджувана територія має задовільну оцінку. В иілому на території області наявні всі фізико-географічні фактори для подальшого перспективного розвитку туристичного кластеру.

Ключові слова: туристичний кластер, фізико-географічні фактори, туристичний ринок, кліматичні ресурси, рекреаційні ресурси, водні ресурси, рельєф, Харківська область.

С. И. Решетченко, Н. И. Черкашина, Е. В. Бабаева. ФИЗИКО-ГЕОГРАФИЧЕСКИЕ АСПЕКТЫ ФОРМИРОВАНИЯ ТУРИСТИЧЕСКОГО КЛАСТЕРА ХАРЬКОВСКОЙ ОБЛАСТИ. В статье рассматриваются основные физикогеографические факторы (климатические, водные, лесные, рельеф) формирования туристического кластера на территории Харьковской области. Кластерный подход позволяет определить приоритетные направления развития туристической деятельности, максимально использовать природнье условия и проводить природоохраняемье мероприятия. Сегодня туристический кластер рассматривают как инновачионную форму развития региональной экономики, поскольку туризм является одним из факторов социально-экономического функиионирования территории. Туристическо-рекреационная деятельность также имеет главное значение в международно-экономических связях. Формирование туристического кластера территории позволит эффективно использовать все доступные туристическо-рекреационные ресурсы территории. Исследование климатических показателей проводилось с помощью статистического метода, где анализировались временные ряды среднемесячных значений температуры воздуха, атмосферных осадков, солнечной радиации за период 2001-2015 года. По методике Н.В. Фоменко было определено, что территория Харьковской области для рекреации и туристической деятельности по показателям «климат», «лесные ресурсы»" «рельеф» характеризуется оченкой «хорошо». В то же время по показателю «водные ресурсы» исследуемая территория имеет удовлетворительную оценку. В изелом на территории области наличествуют все физико-географические факторы для дальнейшего перспективного развития туристического класmера.

Ключевые слова: туристический кластер, туристический рынок, климатические ресурсы, рекреационные ресурсы, водные ресурсы, рельеф, физико-географические факторы. Харьковская область.

Formulation of the problem. In recent years, the cluster approach has become a key tool of tourism policy in the leading European countries. However, our country still has little experience in creating tourist clusters, since it is a relatively new direction in tourism development. In addition, Ukraine has insufficiently developed legal and informational support for creation and operation of tourist clusters.

To assess the potential of tourist cluster development in Kharkiv region it is necessary to analyze a number of factors, such as natural-geographical, historical-cultural and socio-economic ones, which determine the creation of a regional tourist market.

Analysis of recent research and publications. Many works by foreign and Ukrainian scholars, including A. Trebukh [12], S. Sokolenko [9], M. Porter [6], M. Rutinsky, T. Tkachenko [11], I. Dyshlovoi [4], M. Slipenchuk and others, are devoted to the theories and methodologies of tourist clusters. A tourist cluster is understood as a set of economic 